\title{
Retraction Note: Meta-analysis of the efficacy of pancreatoduodenectomy with extended lymphadenectomy in the treatment of pancreatic cancer
}

Xinbao Xu ${ }^{1 *}$, Hui Zhang ${ }^{1}$, Ping Zhou ${ }^{2}$ and Lei Chen $^{3}$

\section{Retraction}

The Publisher and Editor regretfully retract this article [1] because the peer-review process was inappropriately influenced and compromised. As a result, the scientific integrity of the article cannot be guaranteed. A systematic and detailed investigation suggests that a third party was involved in supplying fabricated details of potential peer reviewers for a large number of manuscripts submitted to different journals. In accordance with recommendations from COPE we have retracted all affected published articles, including this one. It was not possible to determine beyond doubt that the authors of this particular article were aware of any third party attempts to manipulate peer review of their manuscript.

\section{Author details}

'Department of Hepatobiliary Surgery, Airforce General Hospital of Chinese People's Liberation Army, Beijing 100142, China. ${ }^{2}$ Department of Radiotherapy, Airforce General Hospital of Chinese People's Liberation Army, Beijing 100142, China. ${ }^{3}$ Department of Hepatobiliary Surgery, Peking University People's Hospital, Beijing 100044, China.

Received: 3 March 2015 Accepted: 3 March 2015

Published online: 26 March 2015

\section{Reference}

1. Xu X, Zhang H, Zhou P, Chen L. Meta-analysis of the efficacy of pancreatoduodenectomy with extended lymphadenectomy in the treatment of pancreatic cancer. World J Surg Oncol. 2013;11:311.

\footnotetext{
* Correspondence: xu_xinbao@sohu.com

${ }^{1}$ Department of Hepatobiliary Surgery, Airforce General Hospital of Chinese People's Liberation Army, Beijing 100142, China
}

Submit your next manuscript to BioMed Central and take full advantage of:

- Convenient online submission

- Thorough peer review

- No space constraints or color figure charges

- Immediate publication on acceptance

- Inclusion in PubMed, CAS, Scopus and Google Scholar

- Research which is freely available for redistribution

Submit your manuscript at www.biomedcentral.com/submit
() Biomed Central 